geopolitical level, so far as different communications in today's information space are unlimited, and their influence can be unpredictable. The transition from the biosphere to the noosphere on Earth has taken place since the middle of the twentieth century but the formation of the noosphere is undergoing significant difficulties because the moral values of those who create regulatory mechanisms and the correspondence of all forms of mental activity of a human being as a chief manager of the new system do not always fit with it. The noosphere education concept includes philosophy, scientific basis, methodology, technology, methods and principles of a new health-saving pedagogical approach. The leading challenge of today is to create such an educational system that can initiate self-organization of the individual, who will be psychologically resistant to all addiction types, receptive and capable of internal and external changes dictated by the evolution, having a universal method of cognition and transformation of the inner and outer world in systematic, constructive and intellectual, aesthetic and environmentally friendly manner. Today the worldview crisis defined historically and implemented through the education system determines a number of problems the modern civilization faces, among which the most dangerous are the following: the rupture of biosphere controlling mechanisms responsible for maintaining the equilibrium of mutation pressure on the gene pool and mankind strength; the rapid development antibiological forms of human activity; the impracticability of general humanism postulate; the social mechanisms of human self-destruction; the emergence and launch of qualitatively new capabilities of dovetailing the real world in the virtual one; the preparation and emergence of the intellect of new forms. Bioethical and socio-cultural principles of noosphere education can be namely first regulatory mechanisms that will provide favorable vectors of human development during the transition period to the noosphere. The implementation of the noosphere education concept by teachers and scientists will help harmonize values, spiritual and practical relationships between people and the environment, and thus will allow the mankind to achieve the next stage of spiritual evolution of the planet, namely the Noosphere.

Keywords: civilizational crisis, bioethics, anthropogenetics, noospheric education.

Подано до редакиіï 12.04.2017

UDC: $37.011 .33 .01:(373.5+378)$

DOI: https://doi.org/10.24195/2414-4665-2017-5-9

\author{
Halyna Vaskivska, \\ Doctor of Pedagogy, senior researcher, Head of the Department of Didactics, \\ Institute of Pedagogy of the National Academy of Educational Sciences of Ukraine, \\ 52-D, Sichovykh Striltsiv Str., Kyiv, Ukraine
}

\title{
DIDACTIC ASPECTS OF UPPER SECONDARY AND UNIVERSITY EDUCATION FUNDAMENTALIZATION
}

Scientists consider fundamentalization as not only a necessary process for education upgrading but also as an important didactic issue. Methodologically designed educational process provides a harmonious combination of both general and specialized knowledge. It is obvious that such a combination would be the most efficient if the subjectsubject interaction of spiritual and moral, aesthetic and social values prevails. Fundamentalization of education content of upper secondary and university education is aimed at providing positive changes in mastering the basics of academic, professional and social activities. The paper aims to highlight the importance of upper secondary and university education fundamentalization by means of certain empirical data implementation. Basing on the survey results (questioning, interviewing of teachers and students, reviewing scientific literature) it has become clear that education content fundamentalization is a complicated and significant process. First of all, this kind of education content update should be based on the professional skills of a teacher (a lecturer), whose level must be high, so that national education could reach the world ideals. This is the basic condition that promotes qualitative mastering of knowledge in the educational process of secondary and university education. On the other hand, fundamentalization of education content should include clearly structured, logically rational system of developing not only the knowledge and the skills of students but also their personality traits based on comprehensive or special as well as professionally designed subject components.

Keywords: education content, upper secondary education, university education, fundamentalization, value orientations.

\section{Introduction}

Scientific and technological development, social changes of world history in recent decades have influenced the tasks and objectives of Ukrainian education. On the one hand, the positive paradigm shifts are evident in the student-centered teaching. On the other hand, there is a problem of education content fundamentalization not only at higher educational institutions, but also in the field 
of upper secondary education. The aim of Ukraine to transform economic, political and social aspects determines the development of all spheres of life. Changing human mission in the new system, political and religious views leads to the new requirements to a personality, education and training of a young generation.

In the new information and technological society, education of the nation will be crucial at the competition level. $21^{\text {st }}$ century is characterized by the transition to the high-tech information society where the quality of human potential, level of education and culture of the whole population become essential for economic and social development of the state.

The need for university and upper secondary education fundamentalization is considered to be an important didactic issue. Its urgency lies in considering the possible ways of upgrading education content to make it meet the needs and demands of the subjects of the educational process and the society in general. Despite the differences in approaches to the determination of the education content, the similarity in the arguments of scientists is clear. The common thing between all research studies is their focus on the dependence of secondary school or university graduates' required level of knowledge on comprehensive scientific and theoretical training. Optimal educational outcomes can be achieved only upon condition if the constant improvement of the content and structure of knowledge, the mastery of the system is taking place.

A British researcher M. Bloomer considers the following indicators of education quality to be significant: critical understanding of natural and social sciences, humanities and arts, gaining knowledge, skills and professional experience by an individual, livelihoods in the community and privacy, forming the ability to demonstrate key skills in practice [6, p. 20-21].

At the same time, the Ukrainian specialist in the field of didactics O. Savchenko notes that "the methodological basis for determining the content of modern school education lies in universal and national values, orientation at the current and future interests of child's education and development. The content is determined on the basis of its fundamentalization, scientific nature and systematic knowledge, their significance for the social development of a person, humanization and democratization of schooling, ideas of multiculturalism and mutual respect between nations and peoples, secular school [5, p. 322]". V. Ocon, an outstanding Polish specialist in didactics, believes that the content of education must be an ordered whole that consists of elements linked together and with the other main components of a school as a whole [4, p. 106].

Over the past decades, the avalanche-like information stream was caused by the rapid development of science and technology. This led to the search for the new education paradigms. According to the academician S. Honcharenko, "the amount of knowledge and the number of subjects in secondary schools and universities increased faster than the methods and the education content were improved. The resources of the extensive education development have been exhausted, and secondary schools, as well as higher educational institutions faced the need for finding intensive teaching technologies $[2, \mathrm{p}$. 4]".

The issue of education content fundamentalization is rapidly acquiring relevance in the field of higher education, as it is demonstrated by the research studies of Ukrainian and foreign scientists. Some authors understand fundamentalization as advanced training in a particular area which is traditional university education. Others interpret fundamentalization as a comprehensive humanitarian and natural science education based on the mastery of fundamental knowledge. In general, fundamentalization is treated as a process that leads to the fundamental nature.

We believe that the current education content in Ukraine should be a scientifically substantiated system of general cultural and national values and the corresponding set of socially relevant traits of a personality that characterize his/her attitude towards the society and state, other people, himself/herself, labor, nature, art [1, p. 167]. In general, all researchers are unanimous in the idea that education content should reflect the needs of the society and include the interrelated elements of social experience.

The paper aims to substantiate the importance of fundamentalization for both upper secondary and university education.

\section{Research methods}

In order to solve this urgent didactic problem, we applied a number of methods, including surveys (questioning; interviewing) of teachers and senior school students, teachers and $1^{\text {st }}$-year students, qualitative analysis of the educational process.

\section{Discussion}

Every society has the achievements that it has accumulated during its entire development. The evolution of any society depends on the development of every citizen. The desire of the Ukrainian society to live and work under the conditions, which are provided in European countries, is quite clear. Since education pays a significant role in this process, is it possible to speak about the quality of Ukrainian education that will ensure the proper social development? 209 teachers and lecturers were interviewed. $14.35 \%$ of teachers (lecturers) indicated that subjects (disciplines) were overwhelmed with outdated information which was not functional enough and did not provide for a widespread use of new educational technologies. $11.01 \%$ of respondents believe that there is a need to review the existing educational standards and improve them. According to $33.49 \%$ of the respondents, imperfect textbooks have a negative impact on education quality. The quality of the different types of educational books is low because the curriculum is changed frequently, does not take into consideration the achievements of modern theory and methods of teaching (this is the point of view of $32.06 \%$ of respondents). 
It is clear that all the abovementioned problems are specifically related to the education content as it is traditionally included in standards, curriculum and textbooks.

If the main objective of traditional school education was to give knowledge, which would be applied by students for the whole lifetime, the task of the modern school has fundamentally changed, especially due to the increased flow of information, the technologizing of all aspects of life. Curricula, teaching plans of traditional schools were designed on the basis of reflecting the scientific principles of academic subjects. However, it is a common knowledge that every science is being enriched by new knowledge that must be considered in the education content. The selection of education content was often guided by the encyclopedic principle. On the other hand, the attempts to introduce large scale, modern, newest advances in science and culture and all their history have led to the overload of curricula and textbooks. The desire to make students gain the appropriate level of culture and science creates contradictions associated with the desire to defend children's health, their intelligence from overload. O. Savchenko believes that instead of forming abilities and practical skills encyclopedic nature of school education and redundancy of the material in the education content make children's memory burdened. The principle of encyclopedic nature has fallen short of expectations. The survey of secondary schools graduates in Ukraine indicates that a great part of their knowledge is not implemented in real life.

Academic overloading of school and university students with unnecessary educational information becomes a negative factor that causes their health deterioration. One way to prevent this and other negative phenomena is the modernization of education content in the area of its fundamentalization that makes its content meet the following requirements: integrity, generalization, universal nature, practical significance of knowledge. Only by means of the in-depth revision of the existing education content, we can expect positive changes in the modern society. After all, scholars, teachers, school students and graduates are sure that school education is overloaded with unnecessary knowledge that is not required by an average citizen.

The empirical data presented in Table 1 states what kind of knowledge is missing (503 senior school students and $4301^{\text {st }}$-year university students were interviewed).

Table 1.

Self-assessment of the insufficient knowledge that is required in upper secondary and university education

\begin{tabular}{|l|c|c|c|c|c|}
\hline \multirow{2}{*}{$\begin{array}{c}\text { educational process } \\
\text { subjects }\end{array}$} & \multicolumn{4}{|c|}{ INSUFFICIENT KNOWLEDGE DEALING WITH.. } \\
\cline { 2 - 5 } & $\begin{array}{c}\text {..human } \\
\text { being }\end{array}$ & ...society & ...nature & ...technique & ...technologies \\
\hline $\begin{array}{l}\text { Upper secondary school } \\
\text { students }\end{array}$ & $34.99 \%$ & $26.25 \%$ & $14.91 \%$ & $15.11 \%$ & $47.51 \%$ \\
\hline $\begin{array}{l}1^{\text {st }} \text {-year university stu- } \\
\text { dents }\end{array}$ & $39.77 \%$ & $37.21 \%$ & $24.42 \%$ & $11.86 \%$ & $62.79 \%$ \\
\hline
\end{tabular}

Taking into account the opinion of theorists and the educational process participants concerning the need for fundamental changes in the education content, the issue of upper secondary school and university education fundamentalization appears to be relevant.

The process of education content fundamentalization is its transformation into a solid foundation of spiritual and material, theoretical and practical activities of an individual that involves comprehensive, general scientific, specialized and vocational training of the educational process participants. We consider the following tasks of the education content fundamentalization to be the most significant: identification of key areas of interdisciplinary integration of subjects, formation of the integral worldview based on the interrelationship of humanities and natural sciences; identification and description of basic teaching units of education content, semantic and methodological development of the didactic parts of education content, the creation of a unified methodology of knowledge assessment, the development of upper secondary school and university students' systemic thinking aimed at the synthesis of various knowledge, integration of approaches, multifactorial, interdisciplinary awareness of the issues in the context, environmental, human as- pects, promoting the ability of critical perception, comprehensive evaluation of various phenomena based on their social, economic, environmental and other features; the formation of an initiative, creative personality capable of solving various practical and spiritual problems.

We distinguish the following criteria of selecting knowledge for education content fundamentalization: scientific nature (objective verity, empirical accuracy, logical clarity, reliability), orientation of education content at the functional use of acquired knowledge (profession-oriented knowledge, its practical importance), selecting education content in terms of the fundamental nature of knowledge (the ability to acquire new knowledge based on previously gained), modernization of knowledge, education content's focus on the formation of personal values and value-semantic orientations of a student [3, p. 5-23].

In accordance with the objectives and the selection criteria we have taken into consideration the main provisions of education content fundamentalization and identified the following conditions for implementing fundamentalization of education content: implementing the updated curricula and plans into the educational process, developing relevant educational and methodological complex of curriculum fundamentalization (manuals and textbooks, 
assignments and tests to monitor the education quality, methodological guidelines, etc.), didactic conditions designed to use system-integrated approach to structuring educational knowledge with designing consolidated didactic units, which are systematic and integrative learning modules, applying modern teaching technologies (project, problem-based, research-based, integrated, modular, etc.), developing axiological attitude towards knowledge, stimulating processes of self-development and self-education, motivating young people to obtain a scientific degree (higher education), etc.

\section{Conclusions}

The education content fundamentalization involves strengthening its fundamental core which is a basic content component necessary for gaining knowledge, skills and values of modern youth and will be applied in all areas of life including spiritual, physiological, professional, everyday activity, etc.

We have distinguished the following main determinants of the education content fundamentalization: preservation and development of the civilization by accumulation, reproduction and transmission of social experience from generation to generation as the foundations of material and spiritual culture, reproduction of human culture through the development of a particular personality, providing a system level of the reality cognition, the ability to see and apply the mechanisms of processes' and phenomena's self-organization and self-development, acquiring the most significant, sustainable, long-term scientific knowledge which is a basis of holistic perception of the scientific worldview, human interaction with nature through humanitarian and technical activities, etc. Self-education plays an important role, because "if a student is aware that he/she has insufficient knowledge or

\section{REFERENCES}

1. Vaskivska, H.O. (2012). Formuvannia systemy znan pro liudynu $v$ uchniv starshoi shkoly: teoriia i praktyka [Formation of a system of knowledge about a human for the high school students: theory and practice]. Kyiv: Vyd-vo NPU imeni M.P. Drahomanova [in Ukrainian].

2. Honcharenko, S. U. (2008). Fundamentalizatsiia osvity yak dydaktychnyi pryntsyp [Education fundamentalization as a didactic principle]. Kyiv: Shliakh osvity [in Ukrainian].

3. Vaskivska, H. O., Baranovska, O. V., Zakharchuk, N. V., Kyzenko, V. I., Kosianchuk, S. V. at. al. (2015). Kontseptsiia fundamentalizatsii zmistu osvity u starshii shkoli $\mathrm{v}$ umovakh profilnoho navchannia [The concept of education content fundamentalization in high school in terms of profession-oriented education]. Dydaktyka: te-

\section{ЛІТЕРАТУРА}

1. Васьківська Г. О. Формування системи знань про людину в учнів старшої школи: теорія і практика : монографія / Г. О. Васьківська. - К. : Вид-во НПУ імені М.П. Драгоманова, 2012. - 512 с. skills to work in a particular area of social interaction and communication, he/she improves his/her knowledge and skills by himself/herself through self-education [7, p. 57]"'.

In order to achieve a positive outcome an education metastrategy (that is a system of basic methodological approaches) should be also developed. These approaches provide quantitative and qualitative parameters of the content of upper secondary and university education. Therefore, there is a need for building a common basic semantic thesaurus, containing important images which should be studied or assimilated to a greater or lesser extent. At the same time, it is possible to create such an extra semantic thesaurus that will combine images that are conceptually relevant to two or three subjects. Combining semantic thesauri will help to develop a common creative field for basic subjects, identify leading semantic configurations and thus enable the formation of education content that would satisfy individual's, society's and state's needs.

Based on the survey results, we can summarize that education content fundamentalization is a complicated and significant process. First of all, this kind of education content update should be based on the professional skills of a teacher (a lecturer), whose level must be high, so that national education could reach world ideals. This is the basic condition that promotes qualitative mastering of knowledge in the educational process of secondary and university education. On the other hand, fundamentalization of education content should include clearly structured, logically rational system of developing not only the knowledge and the skills of students but also their personality traits based on comprehensive or special as well as professionally designed subject components.

oriia i praktyka - Didactics: Theory and Practice, (pp. 523) [in Ukrainian].

4. Okon, V. (1990). Vvedunie v obshchuyu didaktiku [Introduction to general didactics]. Moscow: Vysshaya shkola [in Russia].

5. Savchenko, O. Ya. (2008). Zmist zahalnoii serednioi osvity [Secondary education content]. Entsyklopediia osvity - Encyclopedia of Education (pp. 322-324). Kyiv: YurInkom Inter [in Ukrainian].

6. Bloomer, M. (1997). Curriculum Making in Post16 Education. The Sosial Conditions of Studentship. London: Routledge [in Grand Britannia].

7. Vaskivska, H. (2013). Socialization of the High School Students in the Process of the System of Knowledge about Human Formation. The advanced science journal, 3, 55-58 [in United States].

2. Гончаренко С. У. Фундаменталізація освіти як дидактичний принцип / С. У. Гончаренко. - К. : Шлях освіти, 2008. - Вип. 1. - С. 2-6. 
3. Концепція фундаменталізації змісту освіти у старшій школі в умовах профільного навчання / авт. кол.: Г. О. Васьківська, О. В. Барановська, Н. В. Захарчук, В. I. Кизенко, С. В. Косянчук та ін. // Дидактика: теорія і практика : зб. наук. праць. - К. : Вид-во Ін-ту обдарованої дитини НАПН України, 2015. - C. 5-23.

4. Оконь В. Введение в общую дидактику / В. Оконь. - М. : Высшая шк., 1990. - 237 с.

5. Савченко О. Я. Зміст загальної середньої освіти / О. Я. Савченко // Енциклопедія освіти / Акад. пед. наук України; гол. ред. В. Г. Кремень. - К. : Юрінком Інтер, 2008. - С. 322-324.

6. Bloomer M. Curriculum Making in Post-16 Education. The Sosial Conditions of Studentship / Martin Bloomer. - London : Routledge, 1997. - 235 p.

7. Vaskivska G. Socialization of the High School Students in the Process of the System of Knowledge about Human Formation / G. Vaskivska // The advanced science journal. - Torrance, CA, United States. - 2013, January. - Issue 1. - P. 55-58.

Галина Олексї̈вна Васьківська, доктор педагогічних наук,старший науковий співробітник, завідувач відділу дидактики Інституту педагогіки Національної академії педагогічних наук Украӥни, вул. Січових Стрільиів, 52-Д, м. Київ, Україна

\section{ДИДАКТИЧНІ АСПЕКТИ ФУНДАМЕНТАЛІЗАЦІї ЗМІСТУ ОСВІТИ СТАРШОЇ І ВИЩОЇ ШКОЛИ}

Науковий світ фундаменталізацію вважає не тільки необхідним процесом оновлення (якісної зміни) вищої освіти, але й важливою дидактичною проблемою. Нині фундаменталізацію можна вважати і методологією, що вказує на шляхи формування нових інваріантного та варіативного компонентів змісту освіти старшої школи. У такий спосіб вибудуваний освітній процес передбачає гармонійне поєднання як загальноосвітніх, так i спеціальних знань. Звісно, таке поєднання буде максимально ефективним за превалювання у суб'єкт-суб' єктній взаємодії духовних і моральних, естетичних і соціальних цінностей. Фундаменталізація змісту освіти старшої і вищої школи покликана забезпечити позитивні зрушення у сфері опанування основ навчальної, професійної і соціальної діяльності. Однак, як ми виявили у своїх дослідженнях, важливо ще в шкільному віці формувати здатність особистості до цілісного професійно спрямованого мислення як передумови подальшої активної творчої життєвої і професійної самореалізації. Мета статті - на конкретних емпіричних матеріалах окреслити важливість фундаменталізації змісту освіти як для вищої, так і для старшої школи. Для розв'язання цієї актуальної дидактичної проблеми ми скористалися низкою методів, серед яких: опитування вчителів і учнів, викладачів і студентів-першокурсників, анкетування; інтерв'ю і бесіди; якісний аналіз освітнього процесу; методи спостереження тощо. Результати дослідження спрямовано на розв'язання порушеної проблеми у контексті наближення українського суспільства до європейських цінностей. Подано результати опитування вчителів і учнів щодо дійсного стану проблем сучасної української освіти. Проаналізовано зміст освіти у старшій школі. Обгрунтовано необхідність удосконалення чинного змісту освіти на засадах його фундаменталізації, яка зумовлює гуманізацію процесу навчання і виховання, сприяє формуванню вільної, творчої та оптимістичної особистості.

Ключові слова: зміст освіти, старша школа, вища школа, фундаменталізація, ціннісні орієнтації.

Submitted on April, 13, 2017 